FACTA UNIVERSITATIS

Series: Physical Education and Sport, Vol. 17, No 2, 2019, pp. 259 - 275

https://doi.org/10.22190/FUPES190314025J

Professional article

\title{
DEVELOPING SOCIAL COMPETENCIES OF PUPILS THROUGH WORKSHOPS IN PHYSICAL EDUCATION CLASSES
}

\author{
UDC 796.015:316.47:371.381-057.874
}

\section{Bisera Jevtić, Gorana Đorić, Danijela Milošević}

Faculty of Philosophy, University of Niš, Niš, Serbia

\begin{abstract}
The aim of the study is to determine and develop the social competences of elementary school age pupils in physical education classes, through workshops. The center of the author's interest is an introduction with opinions and behavioral patterns according to differences, based on defined criteria and indicators of measurement. It is pointed out that there is the necessity of taking active roles by all participants of the school community in acquiring new competencies in order to cultivate and respect the principles of differences of physical education classes. The study offers new experience about the utilization of the workshop method, forms, and techniques, as well as the possibilities of raising awareness and behavior change when it comes to discriminatory behavior of pupils through physical culture. This also provides the opportunity for further examination of the workshop method in order to implement it in the teaching of physical education.
\end{abstract}

Key words: Social Competencies, Workshops, Physical Education, Communication, Respect for Diversity

Received March 14, 2019/ Accepted October 08, 2019

Corresponding author: Bisera Jevtić

Faculty of Philosophy, University of Niš, St. Ćirila i Metodija 2, 18000 Niš, Serbia

Phone: +381 18514312 •E-mail: bisera@ vaspks.edu.rs

(ㅇ) 2019 by University of Niš, Serbia | Creative Commons License: CC BY-NC-ND 


\section{INTRODUCTION}

Social competencies of pupils are important for the adaptation and realization of quality relationships in the social environment. In the school environment, the role of physical education teachers is to encourage and develop them through teaching and extracurricular activities, creating conditions for the normal psychological and physical development of pupils. This research highlights the importance of developing pupils' social competencies and the need for school culture reconstruction, which involves taking on the active role of all school community participants in acquiring new competencies in order to foster the principle of respecting diversity. However, we are raising the question of how we can encourage pupils to adopt and apply tolerant behaviors in physical education classes.

This study provides new insights into the possibilities of the workshop method in order to adopt tolerant forms of pupils' behavior, but also for the purpose of the measuring of social competencies of pupils when it comes to respecting differences in physical education classes. At the beginning of our study, we will get acquainted with the concept of social competence and its components, putting emphasis on communication and respect for diversity, tolerance, and democracy, as most important for our research. Then we will present the possibilities of the workshop approach and advantages of its use in the physical education process, as well as the methodology used and the obtained results.

The aim of the study is to identify and develop the social competences of elementary school age pupils in physical education classes, through workshops.

\section{Defining the concept of social competence}

In recent years, the focus of scientific research has been on social competencies that are not yet precisely defined, because the behavior and skills needed for successful interpersonal functioning vary depending on the goal that is being set, the age of the child, and the social situation context. Under social competence we can classify different social, emotional and cognitive skills and behaviors that are necessary for successful social adaptation (Petrović, 2007). It is also defined as a positive relationship in the peer group, as success in interpersonal relationships (Petrović \& Zotović, 2007). They are important for the socialization, development, and forming of the personality of each individual. A socially competent individual achieves a better and more successful social interaction by showing understanding, keeping in mind the needs of others, empathy, awareness of the consequences of their own actions, as well as the ability to solve conflicts (Jevtić, 2012). Social competencies are very important for the pedagogical profession because they represent an essential factor that should be possessed by teachers, those who deal with educational goals (Milovanović, 2012). Passivity, uncertainty, poor communication skills, cooperativeness, etc. are present in a personality with undeveloped social skills. Such a person possesses low self-esteem and hardly achieves interpersonal relationships (Milošević \& Ševkušić, 2005), which negatively reflects on normal functioning in everyday life. 


\section{Components of social competence}

In order to understand what a socially competent individual is, it is necessary to mention the components of social competence. One of the classifications offered by Suzić (2005:70) includes the following components:

1. Understanding of other individuals and groups, interpretation of group emotional flows and relationships;

2. Agreement, compliance with the goals of a group or organization, collaborations;

3. Group management: to be a leader and to be guided, creating relationships, ability to assure, organizational skills, team capabilities, division of labor;

4. Communication: active listening, eye-to-eye and non-violent communication;

5. Supporting of others and servile orientation: sensitivity for others' development needs and supporting their abilities;

6. Respect for diversity, tolerance, democracy;

7. Feeling positive affiliation with the nation and civilization.

The quality of the relationship between teachers and pupils depends on the development of the components, and the degree of their development will depend not only on teachers but on other factors, including family and peers. Teachers of physical education should develop all components in the students because some of the goals they aim for are the development of intellectual capacities, independence, and individuality, establishing an emotional balance and securing social integration (Demirhan, 2003). Physical education should focus on holistic and humanistic pedagogy (Singleton \& Varpalotai, 2012) because such a pedagogical approach of teachers is positively reflected in the prosocial behavior of an individual.

We will focus our attention on communication and respect for diversity, tolerance, and democracy, as the most important components (of all the previously mentioned) for our measurement of social competences through physical education.

\section{Communication as a component of social competence in physical education classes}

Communication skills are of great importance for interpersonal relationships. It is therefore important that the transmitted message is clear, distinctive, concrete and has content, but above all simple. Otherwise, there will be a misunderstanding or a disturbance of relationships. Quality communication in physical education "enables a work load suitable for the abilities of each student, but it also promotes physical education as a reciprocal action in small and large groups, where students gain experience and understand the necessity, benefits and conditions of team work" (Jovanović \& Zdravković, 2017:196). In order to achieve positive communication, a teacher in the classroom needs to be empathetic, flexible, involved and interested in conducting interaction, to know the situation and the group with which he communicates. Such a teacher enables a positive climate and shows openness to hear and accept the opinions of pupils (Mustafičić, 2013). What the relationship between the teacher-pupil and pupilpupil will be depends not only on verbal but also on non-verbal communication. Therefore, it is emphasized that the tone of the teacher's voice is more important, the expression of the face, the position of the body, which all reveal the relationships with pupils (Lalić-Vučetić, 2008). It is extremely important that pupils establish positive 
communication with their teachers. Understanding and accepting pupils are reflected positively on their creativity and productivity while gaining the feeling that they are loved (Ozsezer \& Saban, 2016). The influence of teachers is also significant in shaping pupils' values. Although pupils assume the importance of the values themselves, the teacher is nevertheless the one who helps them through the way of interaction and directs them to reach those values (Wiel, 2003).

It should also be emphasized that pupils are more satisfied with school and their teachers if they have a good relationship with their friends. This tells us about the interconnection and condition of certain indicators of the psychosocial climate. Pupils love school, and they gladly go to it for social interactions, which means that if peer relations are better, the pupil's attitude will be more positive towards the school (Joksimović, 2004). The relationships between teachers and pupils influence, as far as we can see, the acceptance of pupils by peers. If a teacher fails to establish positive communication and continuously enters into conflict with a particular pupil, it is likely that this pupil will be rejected or neglected by peers (Hughes, Cavell, \& Willson, 2001).

In studies of communication between teachers and pupils, some authors (Joksimović, 2004; Jovanović, 2009) point to the need for better communication between teachers and pupils in school and through the teaching process of physical culture. The answers of the pupils indicate that in relationships with teachers there are no equal relations and mutual cooperation. It has been noticed that there is a lack of understanding of pupils' needs and feelings and that teachers do not attach importance to the opinions of students. Pupils would like teachers to show greater understanding and respect for their opinions, but also to talk to them about problems that do not concern teaching content. In order to develop a favorable climate in physical education classes, it is necessary for a teacher to be a socially competent person since he/she creates opportunities for the development of students' social skills by developing mutual relationships through various activities. A teacher's competence is reflected not only in the possession of knowledge and skills but also in encouraging mutual understanding, self-esteem and respect for others, as well as developing leadership abilities (Unlu, Sunbul, \& Aydos, 2008; Centra \& Pootter, 1980). Such a teacher puts effort into developing positive communication during classes, which is a precondition for a quality relationship and mutual cooperation in all relations.

\section{Respect for diversity, tolerance, and democracy in physical education}

According to Goleman (2007) social competence consists of: empathy, sensitivity for the feelings and perspectives of others, respect for diversity, adaptability and prosocial behavior, creating relationships with others, supporting others, a feeling for the development needs of others and supporting their abilities, influencing others, cooperation and teamwork, which is of great importance in educational work. In order to develop social competencies (in particular the moral dimension of personality), an individual's constant engagement and learning of tolerance in every aspect of society are necessary. However, in acting towards others, one should have in mind that the boundaries of the compromise are not indefinite, i.e., that the tolerance of an individual's behavior ends when another person is being violated or threatened (Jevtić \& Ivanović, 2015). Tolerance includes privacy rights, freedom of speech and public appearance (Vujčić, 2003). The basis of democratic dialogue is tolerant communication, and education for democracy is impossible to achieve without accepting plurality in 
schoolwork. In order to develop a pluralist-oriented individual, it is necessary to harmonize the factors of education and own progress interest. The greater the pluralism, the greater the chances of forming healthy interactions between social groups, and the entire society (Jevtić, 2015).

In the education system, the question of education about democracy, that is, the mutual relation of personal, ethnic and national identity is increasingly being considered. Therefore, in the development of an individual, in talking about intercultural dialogue, the school plays a major role. With the help of education, pupils can learn about different cultures, but also the similarities between their own and other peoples' culture. Developing empathy promotes tolerance towards other nations and traditions, and therefore diminishes the possibility of stereotypes, prejudices and discrimination (Đurišić-Bojanović, 2006). Thus, in order to have healthy relations in the school community, mutual understanding of different lifestyles and values is necessary. Basic ethical and cultural values should be mutually respected and equally worth among pupils. This is achieved by developing critical thinking and pluralism (Čačič-Kumpes, 1996). In order for a pupil to develop humane values and to act prosocially, it is necessary to acquire knowledge about this, but also the ability to participate in the school community and a democratic society. On the other hand, it is necessary for teachers to support and guide this process, and to positively affect the formation of school culture with their teaching, which will succeed through the development of social competencies (Jevtić \& Ivanović, 2015; Jevtić \& Mikanović, 2017). There is a pedagogical approach in ten components that have an influence on the quality of teaching physical education, which refers to the teacher's attitude toward pupils (Pill, 2004). Knowledge about the importance of the teacher-pupil relationship indicates that it is crucial for effective teaching and that work outside of regular classes is a good way to get to know students' differences and to achieve better relationships (Whittle, Telford, \& Benson, 2018).

When it comes to school, the task of all participants is to create a climate in which every child will feel safe and accepted. Teaching physical education enables the encouragement of teamwork and association among students. It should be pointed out to pupils that it is not the essence to reduce differences but to help others understand them and act in accordance with the best interests of the individual. When there is no tolerance and respect for differences, there is no possibility for creating equal opportunities, and another possibility for achieving quality relationships is the teaching of physical education.

\section{Concept and specificities of workshops}

After the first part, in which we talked about the concept of social competence, its components and the significance of its development, in this section we will be introduced to the workshop approach and the possibilities for measuring social competences.

The workshop involves a specific method of work which includes the engagement of a group of people who acquire new knowledge together, exchange experiences, demonstrate creativity and find solutions to various problems (Ørngreen \& Levinsen, 2017). Unlike other methods and techniques, workshops provide an opportunity for their combination, which represents their advantage. Such an approach ensures group dynamism and equality not only between participants but also between participants and 
facilitators (Johnson \& Onwuegbuzie, 2014). Workshop activities promote interaction among participants, giving us the opportunity to consider how they look at each other, whether there is a positive or negative interdependence or if they are even not in correlation, which is in accordance with the theory of social dependence (Jacobs \& Seow, 2013). Each workshop contains introductory, main and final activities. Introductory and final activities encourage good relationships among participants (drawing, moving, writing, dancing, etc.), and through main activities, they process selected topics through work in pairs and smaller groups. After each activity participants have the opportunity to express their opinions, attitudes, and feelings (Buljubašić-Kuzmanović, 2006). Workshops provide teachers with the opportunity to develop and improve practice, and pupils to learn and develop their competencies through cooperation (Ørngreen \& Levinsen, 2017). Therefore, the advantage of the workshop method is that it provides the possibility of processing various teaching contents, such a way of working is more interesting for pupils, and provides teachers with the knowledge that they cannot get through classical teaching. When it comes to teaching physical education, the workshop approach allows interconnection of activities that influence proper growth and development, with activities aimed at educational goals.

Workshops, as a method of work, not only allow more dynamic work and the combination of different techniques, but for the purposes of this paper, they are used as a scientific method. Ørngreen and Levinsen (2017) use their workshops as a research method aimed at obtaining reliable and valid data in their research. They point out that the researcher is focused on quality, and together with the participants contributes to the joint process. Thus it is an issue of different methodological issues. In contrast to classical measurement (questionnaire, interview, focus group ...), our designed workshop measures the students' social competencies based on observation, their participation and response in activities. Another advantage is that at the same time we evaluate the effect of the workshop on building social competencies, which set the basis for our other work in which we want to advocate for the workshop method as a method that can give positive results in teaching.

\section{METHODS}

The problems of the research are: How do we measure and recognize tolerant forms of pupils' behavior through a specially designed workshop and how do we encourage pupils to adopt and apply tolerant forms of behavior in physical education classes?

The research starts from the goal: to get acquainted with the positive and negative attitudes and behaviors toward diversity, as well as to develop awareness of the relationship with oneself and others.

The workshop was designed for the needs of this research. It was used as a qualitative method - analysis of student behavior through participation in the workshops. The workshops used an introductory play (introducing and introduction) and a final game (the "end game"). The techniques that were used were: the viewmeter and role play. The forms of work that were realized are: simultaneous individual activity, work in small groups, group discussions, and discussions in the circle. At the beginning of the workshop with pupils, rules were defined that were equally valid for the workshop leader. The rules are formulated to describe desirable behavior, and they are: the rule of the 
circle - in the workshop everyone sits around in order for the participants and leaders to see and hear better; the "next" rule - if someone does not want to, for some reason, participate in the current activity, they can say "next"; the listening rule - participants are expected to listen carefully to each other; rule of participation - everyone participates, there are no observers; rule of respect of the agreed time - everyone respects the agreed time for work; there is no delay, or going out during the workshop (the one who is late to the workshop, is obliged to sing something in front of the group); we use the phone after the workshop.

The workshop was realized in the elementary school "Učitelj Tasa" in the territory of the city of Niš, with pupils of the seventh and eighth grades - 120 pupils in total. The workshop was done in six groups of pupils.

\section{Process of workshop}

In this section, we will show the sequence of activities that make up the structure of our workshop. The activities were created according to the research needs, which are in accordance with the criteria, age, and the number of pupils. The designed workshop gives pupils the opportunity to express their opinions and behavior according to their differences, and on the basis of this, we measure (through indicators) the development of their social competences.

Table 1 presents the workshop activities (first column), criteria for social competences (second column), and indicators of the criteria of social competences (third column), based on which we measured the development of pupils' social competences by assessing their behavior during the realization of the workshops. The objectives of the workshop activities presented in Table 1 are: a. mutual introducing of students by highlighting similarities and differences (activity 1); b. creating positive interaction and a favorable pedagogical climate for work (activity 1); c. adoption of assertive communication (activity 2); d. learning about pupils' attitudes about tolerance towards diversity (members of different religions, nations, social status, etc.) (activity 3); e. to experience and understand the discriminated (rejected) person and the manner of behavior of all actors (activity 4); f. to suggest a different way of resolving the conflict (activity 4).

The workshop approach enables pupils to develop their social skills in a completely different way in physical education classes. This can positively affect their behavior towards others, when it comes to cooperation during the game, understanding of the diversity, and the opportunities and talents that children have when it comes to sports. 
Table 1 Description of individual activities, criteria, and indicators for measuring pupils' social competences

Activity description
Activity 1 - Introductory game:
Introducing (Objectives a and b)
All of them stay in a circle and an
educator instructs everyone to say
their own name and to point out
what they think is unique only to
them. It may be related to interests,
hobbies, food, habits, etc. The
participants who find themselves
similar take a step forward until a
person says something different
from the others.

Activity 2 - Be subtle!

(goal c)

Students are divided into pairs (depending on the number of members), and then pairs receive cards with the following content: Give salt!, Get off my seat!, Shut up!, Mom, you re annoying!, Get out of my room!, Hey, do not touch my stuff!

Pairs of participants translate this form of expression into socially acceptable, unoffensive sentences, and open up the possibility for good communication and successful problem-solving. After that, the presentation of the written material and discussion follow.

Criteria
- Cooperation (skills necessary
for teamwork and active
action of an individual in
solving common goals);
- Communication (mutual
respect, openness, ways of
exchanging messages, etc.).

Indicators

- Mutual respect is evident in the

relationship when there is acceptance

of a different opinion, a calm tone of

speech when the interlocutor does

not interrupt;

- Social reticence is perceived by showing fearfulness, insecurity, mistrust, and lack of social

relationships with others (avoidance of participation in the game, redness, stage fright, etc.);

- Openness, spontaneity, and sincerity (free and relaxed behavior with others, without hidden motives)

- Communication takes place in all directions;

- Cooperation (skills necessar for teamwork and active action of an individual in solving common goals);

- Self-control (the intensity of emotional reactions);

- Empathy (taking different perspectives, recognizing and interpreting others' thoughts, intentions, and fee-lings);

- Communication (mutual respect, openness, ways of exchanging messages, etc.);

- Ability to peacefully resolve conflicts (compassionate communication, announcement and understanding of one's own and others' needs)

- There is a desire to establish interaction with peers and with their pairs;

- Acceptance of the assigned pair;

- Showing the ability of active listening to the interlocutor, so that there is no interruption during the conversation, by showing non-verbal signs (nodding, the body leaning towards the interlocutor) and verbal (confirming "yes", asking questions);

- In conversation with the interlocutor they are pleasant, addressing with a calm tone, showing openness, spontaneity, and honesty;

- There is respect for another's opinion;
- Demonstrating the skills of assertive communication, meaning that they translate the messages into a socially acceptable way, expressing their own attitude, but do not endanger the position of another.

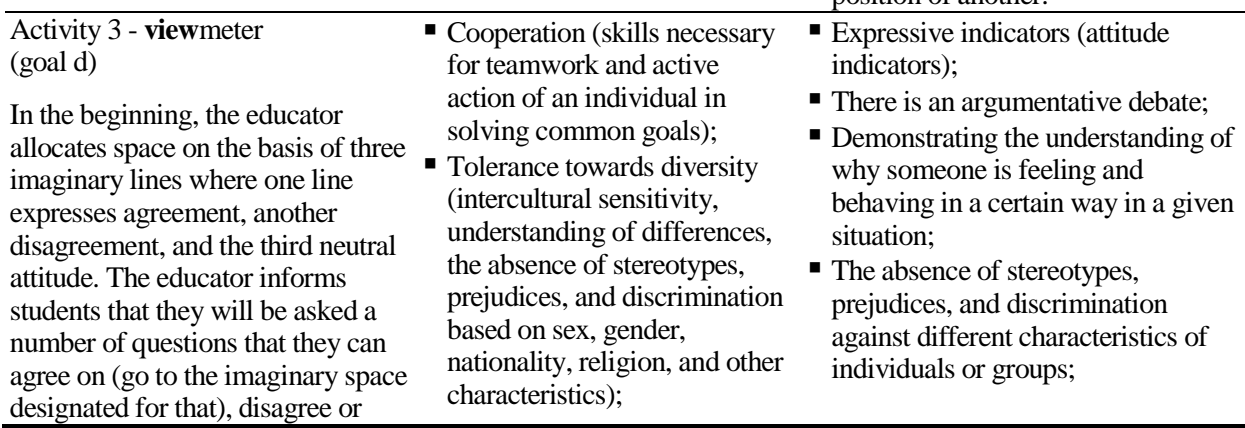




\begin{tabular}{|c|c|c|}
\hline \multicolumn{3}{|c|}{$\begin{array}{l}\text { have a neutral attitude. After each } \\
\text { read-out, the educator raises } \\
\text { additional questions for students to } \\
\text { argue their position. The statements } \\
\text { read: } 1 \text {. When someone is } \\
\text { discriminated, I do not have to do } \\
\text { anything, the victim itself has } \\
\text { caused such a situation; 2. Make } \\
\text { friends with Roma children; 3. } \\
\text { Girls should not play football, } \\
\text { because it is not for them; } 4 \text {. I } \\
\text { would not have a problem if my } \\
\text { best friend was a Muslim; 5. It is } \\
\text { not necessary to socialize with } \\
\text { children who do not have enough } \\
\text { money to go on a field trip; } 6 \text {. On } \\
\text { my birthday, I would not invite a } \\
\text { person from a class who does not } \\
\text { have enough money to buy me a } \\
\text { good gift; } 7 \text {. I can support the } \\
\text { victim of discrimination and } \\
\text { prevent unpleasant situations from }\end{array}$} \\
\hline $\begin{array}{l}\text { An educator forms two groups and } \\
\text { then gives an instruction and pupils } \\
\text { have the task to act out the given } \\
\text { situation. While one group acts, the } \\
\text { other represents the audience. After } \\
\text { the acting, a discussion follows in } \\
\text { order for situations to be resolved } \\
\text { by avoiding discrimination. } \\
\text { The first situation: a new pupil } \\
\text { came to a class. The teacher } \\
\text { represents the pupil. Other children } \\
\text { do not want to hang out with him. } \\
\text { Only one pupil wants to hang out, } \\
\text { but others criticize him and make it } \\
\text { clear that he has to avoid him. } \\
\text { Another situation: five friends sit } \\
\text { on a big break and talk about the } \\
\text { number of followers on Instagram. } \\
\text { One girl's mother does not allow } \\
\text { her to have a mobile phone and } \\
\text { profile on the social network. } \\
\text { Others are mocking her about it, } \\
\text { they do not want to call her on } \\
\text { birthday celebrations, and tell her } \\
\text { she cannot hang out with them. } \\
\text { They say to a girl beside her that if } \\
\text { she still wants to be their friend, she } \\
\text { must increase the number of } \\
\text { "followers" and get a greater } \\
\text { number of "likes" in her pictures. }\end{array}$ & $\begin{array}{l}\text { - Cooperation (skills necessary } \\
\text { for teamwork and active } \\
\text { action of an individual in } \\
\text { solving common goals); } \\
\text { - Tolerance towards diversity } \\
\text { (intercultural sensitivity, } \\
\text { understanding of differences, } \\
\text { the absence of stereotypes, } \\
\text { prejudices, and discrimination } \\
\text { based on sex, gender, } \\
\text { nationality, religion, and other } \\
\text { characteristics); } \\
\text { - Self-control (the intensity of } \\
\text { emotional reactions); } \\
\text { - Empathy (taking different } \\
\text { perspectives, recognizing and } \\
\text { interpreting others' thoughts, } \\
\text { intentions, and fee-lings); } \\
\text { - Communication (mutual } \\
\text { respect, openness, ways of } \\
\text { exchanging messages, etc.); } \\
\text { - The ability to peacefully } \\
\text { resolve conflicts } \\
\text { (compassionate } \\
\text { communication, } \\
\text { announcement, and } \\
\text { understanding of one's own } \\
\text { and others' needs). }\end{array}$ & $\begin{array}{l}\text { - Real presentation of the situation, } \\
\text { through the demonstration of } \\
\text { rejection, ridicule, and insults; } \\
\text { - Listing to the proposals and solutions } \\
\text { of the given situation which indicate } \\
\text { a peaceful resolution of the conflict, } \\
\text { as well as indicating how a } \\
\text { discriminated person should react at } \\
\text { that moment; } \\
\text { - Active action of an individual in } \\
\text { solving common goals, where he } \\
\text { equally participates in the design of } \\
\text { the scenario; } \\
\text { - Equality in the division of tasks } \\
\text { implies respecting the wishes of the } \\
\text { team and taking over the tasks of } \\
\text { team members; } \\
\text { - Confirming/denying the selection of } \\
\text { members to work within the group; } \\
\text { - There is mutual respect, no insult, } \\
\text { ridicule, disrespect, exclusion of } \\
\text { individuals; } \\
\text { - Showing sympathy, which is, taking } \\
\text { different perspectives, recognizing } \\
\text { and interpreting others' thoughts, } \\
\text { intentions, and feelings by } \\
\text { connecting with their own } \\
\text { experiences. }\end{array}$ \\
\hline
\end{tabular}




\section{RESULTS}

In this section, we will show the pupils' answers in all the activities. They were recorded during the realization of the workshop and will be presented entirely. In the introductory game of introduction (activity 1), the pupils' answers are: "I like shooting in free time," "I like playing games, mostly shooters", "I play football, basketball, and volleyball", "I write poems", etc.

Table 2 Pupils' answers in activity 2 - Be subtle!

\begin{tabular}{ll}
\hline Socially unacceptable way & $\begin{array}{l}\text { Pupils`answers } \\
\text { A culturally and socially acceptable way of communication }\end{array}$ \\
\hline Give salt! & "Give me the salt, please." \\
Get off my seat! & "Could you, sit somewhere else, please?" \\
Shut up! & "Calm yourself down, please." \\
Mom, you re annoying! & "Mother, leave me alone, please." \\
Get out of my room! & "Leave my room." \\
Hey, do not touch my stuff! & "Do not touch my stuff, please." \\
\hline
\end{tabular}

Table 2 shows the pupils' responses in activity 2 - Be subtle! The first column contains the messages given to the pupils in order to translate them into a socially acceptable way (second column). In our work with pupils, we were focused on the development and learning of assertive communication and estimation of their development of communication skills.

Table 3 Pupils' answers in activity 3 - viewmeter

\begin{tabular}{|c|c|}
\hline Assertion & The students' answers \\
\hline $\begin{array}{l}\text { 1. When someone is } \\
\text { discriminated against, I do } \\
\text { not have to do anything, } \\
\text { the victim itself has caused } \\
\text { such a situation. }\end{array}$ & $\begin{array}{l}\text { "When discriminating against someone, he/she is not guilty of this, } \\
\text { and such a person deserves to be socialized with." }\end{array}$ \\
\hline \multirow{3}{*}{$\begin{array}{l}\text { 2. It is necessary to hang } \\
\text { out with children of Roma } \\
\text { nationality. }\end{array}$} & $\begin{array}{l}\text { "It is absolutely irrelevant what nationality someone is or anything if } \\
\text { they are okay to me, and that's most important for others."; }\end{array}$ \\
\hline & $\begin{array}{l}\text { "If parents of this child are of the Roma nationality, if they raised him } \\
\text { poorly, for example, to steal, then the child can have bad impact other } \\
\text { children. And if the child is good, why shouldn't I be friends with } \\
\text { him."; }\end{array}$ \\
\hline & $\begin{array}{l}\text { "I have had a both positive and negative experience and I cannot judge } \\
\text { someone just because he is a Roma, but on the basis of friendship and } \\
\text { behavior of the person." }\end{array}$ \\
\hline $\begin{array}{l}\text { 3. Girls shouldn't play } \\
\text { football, because it's not } \\
\text { for them. }\end{array}$ & $\begin{array}{l}\text { "Does it matter whether it is a man or a woman, everyone has the right } \\
\text { to play football, basketball, volleyball, and they can do whatever they } \\
\text { want. It is the same if some boy asks to play volleyball and we say: } \\
\text { "You can't play, you are a boy!", There are girls who train football } \\
\text { because they like it." }\end{array}$ \\
\hline
\end{tabular}


4. I would not have a problem if my best friend was a Muslim.
Discussion of students:

"Croatian maybe, but Albanians and Muslims, no way!"

"We talked about how we should not have stereotypes and prejudices against others, regardless of whether he is a Muslim, Croat or anything else, we mentioned the stereotype that Montenegrins are lazy, so what now, we won't give them any work. You should not judge someone based on one case which we have heard about." "I do not agree with it, because if someone does not respect my religion, why should I respect his."

"How do you know that he does not respect your religion?"

"You, are you using, for example, some social networks, so that you can see when someone writes something against your religion??"

"Everyone writes, it is not one-sided."

"You have a Muslim friend who didn't say anything bad to you, he didn't insult your nation, why wouldn't you hang out with him?" "I do not want to be friend with someone who has killed my nation!!" 5. There is no need to hang "I haven't been to the excursion, but still everyone hangs out with out with kids who don't me."

have enough money to go

on a field trip.

6. On my birthday, I would "That's a stupid reason not to call someone from my class. I mean, I not invite a person from like it when someone buys me a nice gift, but I would never do that." my class who does not have enough money to buy me a good present.

7. I can support the victim "I have a neutral stance because, for example, a few days ago ten of of discrimination and prevent the unpleasant situation from occurring.

\section{them attacked two of them. I can't help there, I can only call the} police.";

"Why can't I help? If I don't do that it is the same as discrimination!"; "We tried to help a friend from my class who was discriminated, but he didn't allow it, and no matter how hard we tried, he refused our help and he didn't want to change his behavior, in order for others to accept him. When we played volleyball on physical education he was kicked out, because he didn't know how to play. I told him: "Come to my team!", and he was very pleased about it."

The answers of pupils in Table 3 relate to their attitudes and actions towards diversity (members of different religions, nations, social status, etc.). We endeavored to develop tolerant forms of behavior and to get acquainted with opinions, attitudes and behavioral patterns towards the target groups that are most often discriminated.

Table 4 presents pupils' solutions (answers) to the given situation. At first, pupils have demonstrated (acted) the situations, and then, through group work, they sought to solve the problem. Answers, or suggestions, indicate a peaceful resolution to conflicts and showing compassion for a discriminated individual. 
Table 4 Pupils' answers in activity 4 - role play

\begin{tabular}{ll}
\hline Answer (solution) of pupils to the first situation & $\begin{array}{l}\text { Answer (solution) of students to the second } \\
\text { situation }\end{array}$ \\
\hline "The teacher should tell them to stop & "It's a very stupid reason - that they do not hang \\
discriminating him, to react. They need to get & out with her because of that and there should be \\
to know each other better, to present this pupil, & someone else to support that girl." \\
and to support a boy who wants to hang out & "When we had a quarrel, it was never because of \\
with him, to confront those pupils who insult & such situations - because of a number of "likes". \\
him." & $\begin{array}{l}\text { That's stupid!" } \\
\text { "It's not easy when someone doesn't want to hang } \\
\text { out with you because of something, for example, } \\
\text { you are punished or your parents do not allow } \\
\text { you to have a phone. It's a very stupid reason and, } \\
\text { of course, everyone will feel bad about it." }\end{array}$ \\
\hline
\end{tabular}

On the basis of defined criteria (cooperation, tolerance toward diversity, self-control, empathy, communication, ability to peacefully resolve conflicts), indicators of measurement and pupils' responses presented in Tables 2, 3 and 4, we have estimated and analyzed the development of pupils' social competencies.

Cooperation - In the introductory game, pupils show spontaneity and openness. Most of them freely communicate and participate. Some express shyness and stage fright (redness, salivary swallowing, temporary delay of participation), and others show a desire for increased participation (giving more answers and suggestions to others what to say). In the activity Be subtle, a great majority of students showed desire to establish interaction with their peers and with their pairs, except for a boy who initially refuses to cooperate because there was an expectation and a desire for his partner to be the best friend. In playing roles, boys showed a desire to make a division into two groups, that is, they wanted a group which consists only of boys, and the girls were not opposed. Girls equally participated in the design of tasks, while in the group of boys an individual decided about taking the roles and style of performance. In the group of girls, the proposals of all were respected, and in the group of boys there was disdain and ignoring of one member's ideas.

Tolerance to Diversity - Based on the answers to the claims in the viewmeter, it was noticed that girls do not show discriminatory behavior, while the boys refuse any contact with members of other religion and nationality, especially with Muslims, Croats, and Albanians. Boys do not give adequate arguments and do not respect the different opinions of the girls. On the other hand, girls show openness when it comes to accepting diversity and a desire to get to know them.

Self-control - In the Be subtle activity, pupils reacted calmly towards each other, but emphasizing that in their private lives they react aggressively with their sisters and brothers. They think that this is normal and that "the other person does not get angry, because that person knows that they do not think anything bad with it". In the viewmeter, boys reacted intensely to the fact that girls showed a different attitude, and each of their comments which differed was perceived as a direct attack. In the last game, in the group where the boys were, there were aggressive reactions to the ideas of one member. 
Empathy - In the discussion after the role-playing, the pupils pointed out that it was interesting, but also uncomfortable when they were discriminating against the boy. They showed the ability to put themselves in the victim's position and to understand the feelings and behaviors in a given situation, by pointing out suggestions and solutions.

Communication - In all activities, communication takes place in all directions. There is an interaction between pupils, but they often interrupt each other, that is, they do not allow others to finish the sentence. Boys show a tendency to increase tone in communication, but also a greater desire for communication. In the game Be subtle they do not see that there is a possibility of hurting another person when it comes to an unsympathetic mode of communication.

The ability to peacefully solve conflict - In the viewmeter and role play, the possibility of assessing how to solve student conflicts is seen. When there was a conflict between girls and boys in expressing different attitudes, there was no compromise, so we had to close the debate after a long discussion. Role play achieved a positive effect, as pupils have put forward suggestions and solutions to given situations that suggest a peaceful resolution of conflicts, as well as indicating how a discriminated person should react at that moment.

On the basis of defined indicators of pupils' behavior measurement, which with we measured social competencies, we identified stereotypes and prejudices, that is, a low level of tolerance towards different nations and religions. On the other hand, on the basis of their attitudes and experiences, we learned that pupils help discriminated pupils, accepted and looked equally at pupils of different achievements, social status, minority members... Only of physical education classes did they emphasize that conflicts are forgotten, because they are focused on the game, and it is known that physical activities aim to develop team spirit and communion. Between the pupils of the seventh and eighth grades, we found that there are no differences in the answers. Differences were expressed on the basis of gender in terms of communication and non-acceptance of differences. With expressive indicators, we have estimated that parents have the greatest influence in the formation of pupils' attitudes and that it is necessary to work continuously on the adoption of the principle of accepting diversity. We are convinced that their social competencies are not fully developed, and that this method is suitable for measuring communication and tolerance for diversity.

\section{DISCUSSION}

In this section, we will interpret the results obtained taking into account the criteria and indicators of measuring students' social competencies. Although our research cannot be subjected to generalization, we want to highlight the most significant results that indicate some specific behavior of students at physical education classes, which should be further studied and subjected to new research.

Students' behavior suggests that spontaneity and openness are easier to achieve in a familiar environment and among students of the same gender than with unknown students and students of a different gender. Thus, the differences in responses, and especially in behavior, have been shown in relation to gender in half of the students. While girls showed tolerance to diversity, the boys had a turbulent response to a different opinion (especially when the girls expressed it). Such reactions are present in a familiar environment. On the other hand, strong prejudices against "hostile" ethnic groups of the boys (according to pupils, supported by 
content from the Internet and under the influence of parents) indicate a low level of tolerance and a lack of desire for learning other cultures. Unlike them, girls are less susceptible to prejudice, because they shape their attitudes in accordance with their own experience. Thus, the results regarding tolerance towards diversity show that girls' social competencies are more developed than the boys' competence. This result suggests that primary socialization of gender roles may have a stronger impact on social competencies than the impact of teachers and peers. The relative strength of various influences was not the subject of this paper, but it is a topic that should be addressed in new studies. Regarding empathy, it appeared in the course of the workshop only when the students were put into the role of the victim. This reinforces our argument from the beginning of the work that social competencies in school are best developed through workshops, where pupils have the opportunity to experience discrimination on their own skin (through role-playing). This activity has positively influenced the intensity of boys' emotional reactions, that is, the boys sought to resolve the conflict peacefully, which was one of the goals of the workshop. When it comes to mutual cooperation and decision-making, differences are noticeable in relation to gender, which can be related to the (family) socialization of boys and girls in general (boys tend toward dominance, girls tend toward tolerance). In the activities that measured communication, a low level of culture has been shown (speaking while others are speaking, imposing one's opinion, not listening to others) and complete lack of knowledge of alternative (assertive) modes of communication, from which we conclude that this skill is something that should be learned in the school environment, and perhaps in cooperation with parents.

Our designed workshop proved to be suitable for measuring components (communication and tolerance of diversity) of social competence. The students' responses and their behavior during the realization of the workshop shown that they first meet with this method and that thanks to it, other research questions have been opened in order to improve the teaching of physical education.

\section{CONCLUSION}

In the 21 st century, the social competence of individuals is the basis of socialization, integration, and inclusion in society. Apart from contributing to the establishment of good quality relationships, they help an individual to respond to unacceptable behavior in the social environment.

A healthy school environment evaluates each individual and provides him with equal conditions for advancement. Its fundamental values reside on the postulates of humanity, as it encourages the uniqueness of each individual and the tendency for personal development. Since there are various influences on the formation of such an environment, mutual understanding of different lifestyles and values is necessary, but first of all, growing up in a healthy family that nourishes tolerant forms of behavior and accepts diversity. Through the education of physical education, the need for developing 'democratic education' is recognized, which would contribute to the removal of cultural, religious and ethnic barriers. Democratic dialogue is an initial step towards understanding and accepting diversity and students should be given the opportunity to get to know them, through teaching content, workshop activities and other forms of learning that encourage active participation.

The results of our research are confirmed by some general theoretical statements and based on expectations in the implementation of innovative methods in teaching physical 
education. For example: that the quality of an individual's relationship with others depends on the development of its components; that a quality relationship on all relations requires successful communication; that tolerance is encouraged by the development of empathy, etc. The results of the paper point to the inadequate development of the social competencies of the students of the seventh and eighth grades, especially when it comes to acquiring communication skills and nonviolent conflict resolution, control in regulation and self-regulation of emotions, openness to accepting diversity, based on the criteria and indicators of measurement, we have come to the conclusion that the two components (communication and tolerance to diversity) can be measured, but regarding others (cooperation, empathy, etc.) it is necessary to design a special workshop.

The contribution of our research is recognized in the use of the workshop as a scientific method and the method of developing social competences in students in physical education classes. Although the workshop is used as a scientific method for measuring social competences, it can provide teachers with the opportunity to implement it in teaching in order to improve and innovate it. The contribution of this method in the teaching of physical education is reflected in the achievement of students' integral development. Such a method would contribute to the humanization of the relationship, which also gives teachers the ability to educate themselves. The workshop method can contribute to linking the connection between formal and non-formal education and providing students with the opportunity to learn in a different and more creative way. For the next step, we propose the measurement of other components of social competencies, but also the comparison of the workshop model with classical methods in teaching, as a prerequisite for achieving positive results in working with students.

Our recommendation to actors of the school community is to create programs that will aim at strengthening the capacity of students to actively solve problems in the school environment. Such oriented programs would have an impact on strengthening the feeling of community, associative spirit, fostering friendship, respect for diversity and individual responsibility. We believe that it is also necessary to increase the teaching staff's involvement in the internalization of humanistic values, as the basis for the education of both the individual and the society as a whole.

\section{REFERENCES}

Buljubašić-Kuzmanović, V. (2006). Pedagoška radionica u funkciji aktivne nastave i učenja na uspjesima (Pedagogical workshop in the function of active teaching and learning on success). Metodički ogledi: časopis za filozofiju odgoja, 13(1), 123-136. In Croatian

Centra J.A., \& Potteer D.A. (1980). School and teacher effect: An international model. Review of Education Research, 50(2), 273-291.

Čačič-Kumpes, J. (1996). Obrazovanje i tolerancija (Education and tolerance). Društvena istraživanja-Časopis za opća društvena pitanja, 2(22), 307-319. In Croatian

Demirhan, G. (2003). Physical education and sports philosophical views of teachers. Journal of Sport Sciences Hacettepe University, 14(2), 43-44.

Goleman, D. (2007). Socijalna inteligencija (Social intelligence). Belgrade: Geopoetika. In Serbian

Đurišić-Bojanović, M. (2006). Stavovi mladih prema multikulturalnosti i prihvatanje ideja (Youth attitudes towards multiculturalism and the acceptance of ideas). Zbornik instituta za pedagoška istraživanja, 38(2), 430-444. In Serbian

Hughes, J., Cavell, T., \& Willson, V. (2001). Further support for the developmental significance of the quality of the teacher-student relationship. Journal of School Psychology, 39(4), 289-301. 
Jacobs, G.M., \& Seow, P. (2013). The many co-operative roles available to workshop cofacilitators. Journal of Cooperative Studies, 46(2), 62-68.

Jevtić, B. (2012). Pedagogija moralnosti (Pedagogy of morality). Niš: Faculty of Philosophy, University of Niš. In Serbian

Jevtić, B. (2015). Retro(per)spektiva(a) socijalizacije (Retro (per) spective (e) of socialization). Niš: Faculty of Philosophy, University of Niš. In Serbian

Jevtić, B., \& Mikanović, B. (2017). Students of physical education and sports as victims and bullies, their academic self-concept and interpersonal trust within family. Facta Universitatis Series Physical Education and Sport.15 (2), 283-293.

Jevtić, B., \& Ivanović, M. (2015). Potreba za rekonceptualizacijom humanističkog vaspitanja (Need for reconceptualization of humanistic education). In The Humanistic Ideals of Education, Upbringing and Psychology. Science and Contemporary University 4, (pp. 197-211). Niš: Faculty of Philosophy, University of Niš. In Serbian

Johnson, R.B., \& Onwuegbuzie, A.J. (2014). Mixed methods research: a research paradigm whose time has come. Educational Researcher, 33(7), 14-26.

Joksimović, S. (2004). Komunikacijau nastavi i psihosocijalna klima škole (Communication in teaching and psychosocial climate of a school). Pedagogija, 59(2), 1-11. In Serbian

Jovanović, M. (2009). O postojećoj komunikaciji u nastavi i o neophodnim promenama (About existing communication in teaching and about necessary changes). Nauka i vaspitanje, 58(2), 201-215. In Serbian

Jovanović, M., \& Zdravković, D. (2017). Nonverbal communication and physical education classes in a social context. Facta Universitatis Series Physical Education and Sport, 15(1), 195-206.

Lalić-Vučetić, N. (2008). Kvalitet komunikacije između nastavnika i učenika i primena podsticajnih mera (Quality of communication between teachers and students and implementation of stimulative measures). Zbornik instituta za pedagoška istraživanja, 40(1), 122-136. In Serbian

Milošević N., \& Ševkušić S. (2005). Samopoštovanje i školsko postignuće učenika. Zbornik Instituta za pedagoška istraživanja, 1, 70- 87. In Serbian

Milovanović, R. (2012). Socijalne kompetencije kandidata za pedagoški fakultet (Social competences of candidates for faculty of pedagogy). Nauka $i$ vaspitanje, 61(4), 662-679.

Mustafičić, N. (2013). Verbalna i neverbalna komunikacija kao najznačajniji faktor u kvalitetnoj interakciji učeniknastavnik (Verbal and non-verbal communication as the most important factor in the quality pupil-teacher interaction). In S. Brdarević \& S. Jašarević (Eds.). 8th Research-Expert Conference with International Participation “Quality 2013”, Bosnia \& Herzegovina: Neum.

Ozsezer, M.S.B., \& Saban, A.I. (2016). An investigation on teacher candidates' perspectives about behaviors positively affecting classroom atmosphere. Eurasian Journal of Educational Research, 16(66), 139-158.

Petrović, J. (2007). Socijalna kompetencija: konceptualna i teorijska pitanja (Social competence: conceptual and theoretical issues). Teme, 32(3), 611-623. In Serbian

Petrović, J., \& Zotović, M. (2007). Prihvaćenost u grupi i emocionalna kompetencija dece preadolescentnog uzrasta (Acceptance in the group and the emotional competence of preadolescent children). Psychology, 40(3), 431-445. In Serbian

Pill, S. (2004). Quality learning in physical education. Active \& Healthy Magazine, 11(3), 13-14.

Ørngreen, R., \& Levinsen, K. (2017). Workshops as a research methodology. The Electronic Journal of eLearning, 15(1), 70-81.

Singleton, E., \& Varpalotai A. (2012). Introduction: So little for the body. Pedagogy in motion: A community of inquiry for human movement studies. London, ON: The Althouse Press.

Suzić, N. (2005). Pedagogija za 21. vijek (Pedagogy for 21 century). Banja Luka: TT-Centar. In Serbian

Unlu, H., Sunbul, M. A., \& Aydos, L. (2008). Physical education teachers' competence and the validity-reliability stady. Journal of Education Faculty of Ahi Evren University, 9(2), 23-33.

Vujčić, V. (2003). Toleriranje manjina s kojima se ne slažemo jest tolerancija (Tolerance of minorities with whom we disagree is tolerance). Politička misao, 40(2), 186-191. In Serbian

Whittle, R.J., Telford, A., \& Benson, A.C. (2018). Teacher's perceptions of how they Influence student academic performance in VCE physical education. Australian Journal of Teacher Education, 43(2), 1-25.

Wiel, V. (2003). Moral education from a humanistic perspective. Paper presented at the annual meeting of the American Educational Research Association, Chicago: University for Humanistics Utrecht. 


\section{RAZVIJANJE SOCIJALNIH KOMPETENCIJA UČENIKA KROZ RADIONIČARSKI RAD NA ČASOVIMA FIZIČKOG VASPITANJA}

Cilj rada je utvrđivanje i razvijanje socijalnih kompetencija učenika osnovnoškolskog uzrasta na časovima fizičkog vaspitanja, putem radioničarskog rada. U središtu interesovanja autora je upoznavanje sa stavovima $i$ oblicima ponašanja prema različitostima, na osnovu definisanih kriterijuma i indikatora merenja.Ukazuje se na neophodnost preuzimanja aktivne uloge svih aktera školske zajednice u sticanju novih kompetencija u cilju negovanja i poštovanja načela različitosti na časovima fizičkog vaspitanja. Rad nudi nova saznanja o korišćenju metode radioničarskog rada, oblika i tehnika, kao i mogućnostima osvešćivanja stavova i promene ponašanja kada je reč o diskriminacionom ponašanju učenika kroz fizičku kulturu. To ujedno pruža mogućnost za dalja ispitivanja radioničarske metode u cilju njenog implementiranja u nastavi fizičkog vaspitanja.

Ključne reči: socijalne kompetencije, radionica, fizičko vaspitanje, komunikacija, poštovanje različitosti 